Volume 19

Issue 2 June

Article 11

May 1992

\title{
Organic Communities, Atomistic Societies, and Loneliness
}

Ben Mijuskovic

County of San Diego

Follow this and additional works at: https://scholarworks.wmich.edu/jssw

Part of the Social Work Commons

\section{Recommended Citation}

Mijuskovic, Ben (1992) "Organic Communities, Atomistic Societies, and Loneliness," The Journal of Sociology \& Social Welfare: Vol. 19 : Iss. 2 , Article 11.

Available at: https://scholarworks.wmich.edu/jssw/vol19/iss2/11 


\title{
Organic Communities, Atomistic Societies, and Loneliness
}

\author{
BEN MIJUSKOVIC \\ County of San Diego \\ Department of Health Services
}

The article distinguishes two models of human organization, the organic community and the atomistic society. It maintains that the organic paradigm stresses (a) the ideal unity of the whole; (b) organic or intrinsic relations; (c) living or dialectical processes; $(d)$ the image of "members"; (e) the mutual interdependence of the members; ( $f$ ) a role perspective; and (g) dynamic or natural functions. By contrast, the atomistic construction emphasizes (a) the value of individual freedom; (b) external connections; (c) mechanical or causal explanations; (d) the metaphor of "parts"; (e) the independence of the parts; $(f)$ a rule orientation; and $(g)$ a formalistic, legal, or artificial framework. The paper next contends that the sense of individual loneliness or alienation experienced is generally much greater in the atomistic society. And since both the American family and the society are, in the main, atomistically structured, it follows that loneliness is much more pronounced and prevalent in American society. The article concludes by offering some programmatic ideals and cures to reverse and mitigate the present tendency toward increasing loneliness.

The German sociologist, Ferdinand Tonnies, distinguished two basic forms of social organization, the organic community and the contractual or atomistic society (1957). In this paper, I wish to reformulate Tonnies' models for my own purposes by relating them to a discussion of loneliness.

But before beginning, two things should be noted. First, especially at the macro level of large social and political units, these two paradigms of social organization may not occur in their pure and undiluted theoretical forms. In this context, I will be describing ideal types, which probably do not exist in a perfect form on a grand scale. Nevertheless, both principles or models (I employ these two terms interchangeably) serve, consciously and unconsciously, as goals and accordingly guide their respective participants in their adopted conceptions 
of human interaction and relationship. Consequently, the dual paradigms constitute powerful conflicting tendencies of human organization, which lead in diametrically opposite directions. In this respect, the two principles determine the individual's sense of alienation from-or unity with-the social group with which one is involved.

Secondly, when single individuals or small groups are considered, then it is possible that the characteristics of the twin modes of human existence can be empirically exhibited. Thus, it is quite likely that a relatively isolated but self-sufficient rural family, for instance, actually represents a real organic social structure.

Similarly, it is often the case that solitary transients and recluses primarily function as atomistic individuals, who are either virtually unrelated in any human way to the larger framework of society or, who, if they are peripherally connected to it, express an antagonistic response to that society. At this more constricted level, the organic family or community as well as the isolated individual are both contemporary sociological realities and their actual presence, with all their pertinent implications, must be recognized because they have far-reaching consequences which directly determine the social existence we all experience.

Examples of philosophers who have adopted the organic model would certainly include Aristotle, Hegel, and Marx. But both the earliest and the clearest formulation of the paradigm surely originates with Plato. According to the Republic (1957, IV $441 \mathrm{C}-434 \mathrm{D})$, the structure of classes within the ideal polis should reflect a similarly ideal separation of activities or functions within the human soul (the principle of justice). By the same token, although separate, the diverse functions should also be integrated harmoniously within the soul and state when they perform their various but coordinated activities (the principle of temperance). Thus both the individual human psyche as well as the small city-state should manifest an infrastructure of coordinated activities between its interdependent members. Just as the whole person is constituted by the separate but contributing functions of (a) appetite and desire, (b) spirit or courage, and (c) reason and wisdom, in a corresponding fashion, the ideal 
state should exhibit the cooperative interfunction between the three classes of citizens comprising it, (a) the farmers, artisans, and merchants, (b) the soldiers and police force, and (c) the wise legislators and rulers, who guide and determine policy. Consonant with this paradigm of cooperation, indeed it is a direct implication of it, is the conviction that each person should function or behave in an interdependent and synchronous fashion in relation to the other members involved; implicit in the paradigm is the principle that the various roles together are all required to define the identity of the whole and that if any one role should fail to operate, then the entire organism is transformed in a deficient manner. Consequently, the model incorporates a terminology which is distinctive in emphasizing metaphors of function, role, member, organic whole, etc. To extend the metaphor or picture a little further, it is argued that just as a living animal is healthy when its various limbs and organs are coordinated according to their diverse functions, just so the polis consists of various mutually conditioning operations. For Plato, this means that there is a natural division of labor and qualitative factors are stressed. And if one member or class seeks to usurp the function which naturally and intrinsically belongs to another, the organism adapts poorly (1957, IV 441C-445B).

A further sociological implication of this model is that meaningful relations and activities are essentially internal, intrinsic, since they are mutually defined by all the other elements within the organic whole. Thus they are often described as living, dynamic, human, and dialectical. It follows that no one is selfsufficient. Not only is one born within a family, and therefore the group is primary, but the whole defines the individual and the individual could not exist without it. But more than that, it implies that the good or the happiness of the individual cannot exist apart from others. The individual not only needs the group in order to live but he needs their mutual support in order to be happy or virtuous. This is what Aristotle meant when he said that people are social or political animals; their happiness lies in the polis; and a person apart from society is either a beast or a god but is not human. This obviously dictates a sociological approach-as opposed to a psychological one-in understanding people and their interactions with each other. 
Thus, the individual's well-being can only transpire within the context of a supportive community. This is another way of saying that the value of the person cannot be separated from the person's functions within the whole and both rights and duties have meaning only in the context of an organic unity. Community, defined as a sense of belonging and identity, a reciprocal sharing with others, is natural to us; it is an expression of our essential nature. Hence social actions are determined by functional roles and freedom is conceived as doing as you should in order to promote the good of the whole community. Social duties prevail over individual rights.

Generally, such organic communities are hierarchically structured. The small family consisting of a father, mother, and child, Plato's ideal polis, the medieval Catholic Church, the feudal manor, or Hegel's nation-state are each examples of organic wholes. But sometimes, the hierarchic principle is theoretically violated, in principle at least, as in Marx's concept of the classless community after the final revolution. (Nevertheless, it is quite possible that this theoretic deviation from the model could never have been carried out in actual historical practice.)

For some proponents of the model, most notably Plato and Rousseau, the suggestion is made that the ideal unit contains an optimum numerical population. It should be sufficiently large to carry on diverse activities but not so extensive that all the members do not know each other. In Rousseau, this means direct participation by the citizens in the life of the community, the political organism (1973). Should the organism increase beyond certain naturally determined proportions, then the organism is transformed into a monstrous creature and it becomes an unnatural entity. The empire of Alexander the Great and the Roman empire in its declining stages, were precisely such macrosocial monsters. That is why for Hegel, the ruling principle of organic vitality consists in communal self-consciousness, a spiritual realization of a culture's sharing or a common language, laws, customs, institutions, religion, political ideals, etc. And this self-conscious and hence rational awareness presupposes a historical insight into the dialectical process that brought about precisely those "forms of life" (1977). 
Historical and sociological examples of this principle of social organization are as abundant as they are varied. Sparta during the Peloponesian wars, the Roman republic, the early Christian community, monasteries in the middle ages and today, Robert Owen's New Lanark, the contemporary Japanese factory, many peasant villages in Asia, the California hippie communes, etc., may all serve as ready historical examples of the type under discussion. Sociologically speaking, the nuclear and extended family, the kinship system, the tribe, rural communities, ethnic communities, etc., are alike theoretically grounded in the organic model.

As previously stated, the guiding principle determining the value of the organic community and the criterion of success applied to the social organization behind it lies in its expression of unity; and therefore it follows that the good of the whole is above the value of the individual. That is both the strength and the great danger of this model. For as Hegel warned, it may be necessary for the State to "crush many an innocent flower" (1956, p. 32). Thus, when this form of social organization deteriorates, it tends toward totalitarianism, despotism, dictatorship, the claim that the ruler knows what is best for others and that the party in power should "force men to be free" (Rousseau, 1973). The negative utopia depicted in Orwell's 1984 is a good example of this form of totalitarianism (1949). When this state of affairs exists, then communication breaks down, the sense of belonging and mutually sharing disappears, and an extreme sense of loneliness and alienation is generated in those who are judged as deviant or acting against the good of the whole. An example of this is the recent ostracism or shunning of a father by the members of his own immediate family on instructions from the Mormon Church.

By contrast, in the contractual or atomistic society, the social body is composed of individual parts, rather than members. Together the parts add up to a collection, an aggregate. Whereas the organic community reflected qualitative and functional differences among its members, the contractual society displays primarily quantitative differences-the parts are regarded as equal, interchangeable, replaceable; one part is very much like 
any other. In an atomistic society, then, the social organization is made up of a smaller or larger number, a collection, of qualitatively identical units; each is a unit sufficient unto itself. Some collections or aggregates are small and some are large but there is no inherent limit to the size of the society. Thomas Hobbes' state described in Leviathan (1981, p. 196) is as perfect a model of this conception of people in civil society as Plato's Republic is of the opposite paradigm (1957, II 357A-367E). Other defenders of the atomistic model are the social contract theorists in general, which would include Glaucon, in Republic II, Spinoza, Locke (1946, p. 48), and Rousseau, the latter being inconsistent since he paradoxically argues in behalf of both models.

In the atomistic society, relations are essentially regarded as contractual, external, legalistic, formalistic. Whereas the organic community stresses functional roles, the contractual society emphasizes legal rules. These thinkers regard the individual as completely self-sufficient and capable of surviving apart from others, often in a state of nature, where the laws of civil society (Locke) and morality are suspended (Hobbes). But because there is no impartial judge in the state of nature (Locke) or because life within that condition is "solitary, poor, nasty, brutish, and short" (Hobbes, 1981), one is forced to combine with others for the sake of security and protection. What one would really like to do is to be able to injure others with impunity; what one fears most is being injured without the power of retaliation; so one compromises and promises not to hurt others if they promise the same. Society, then, is the outcome of an artificial agreement. It is unnatural; what is natural is to do as one likes; freedom is doing as one pleases (Glaucon). One should be allowed to pursue one's self-interest as much as possible and hence "that government is best which governs least" over the individual's "rights," i.e., egoistic self-interest. Obviously, in the atomistic model, rights are emphasized over duties; this principle contrasts markedly with the organic value of the individual's duties to the whole.

Whereas in the organic community the good people can only exist on the condition that the community as a whole is goodhence Plato's goal to reform the polis-in the atomistic model, the value of the individual is separate and distinguishable from 
the quality of the surrounding aggregate (1957, II 357A-367E). Accordingly, the dominant value consists in guaranteeing the expression of individual liberty as the highest benefit a society can confer upon its constituents. This value may be reflected at various levels of operation and through diverse institutions. In a religious context, it is grounded in the Reformation principle that individual conscience alone dictates to the individual; economically it is exhibited in Adam Smith's laissez faire principles; in political thought it is exemplified by Locke's liberalism and in social thought by Mill's principle of self-regarding conduct which assures the individual the moral rights of freedom of speech, religion, and association as well as the right to nonconformist behavior (1947).

When Locke proposes that individuals may return to the state of nature when the terms of the civil contract are abrogated, he clearly has in mind the genuine possibility of solitary individuals physically emigrating to the new world and forming a different society. But this sort of atomistic self-sufficiency can be pursued on a spiritual level as well. Thus, Kierkegaard's existential brand of Protestantism describes a path toward individual salvation (1974).

On the larger scale of societal characteristics, the traditional example of an atomistic society is most clearly represented by the Industrial Revolution of the nineteenth century in England, France, Germany, and later in the United States. Correspondingly, a number of sociological works heavily depend upon just this picture of the isolated individual. Thus, it may be said without fear of exaggeration that Weber's The Protestant Ethic and the Spirit of Capitalism (1958), Durkheim's Suicide (1958), and Riesman's The Lonely Crowd (1953), more specifically the concept of the "inner-directed man," and Fromm's Escape from Freedom (1965), Berdyaev's Solitude and Society (1976), all draw on the atomistic individual.

Like the previous model, this paradigm also has its peculiar brand of horror. When this form of social organization tends toward disruption and corruption, it manifests itself in the more virulent instances of capitalism, in states of unbridled competition and anarchy and of social Darwinism; it is a situation of "every man for himself," a war of all against all (Hobbes 1981, 
p. 185). For some, it is a condition wherein the state of nature is indistinguishable from civil society. The numerous examples of civil disobedience and civil war which dominate our contemporary times serve as obvious examples of this attitude toward human existence.

As previously intimated, these opposing models, the organic and the atomistic, have far-reaching implications in connection with the feelings of loneliness involved in the contrasting paradigms. In the organic model, generally speaking, the tendency is toward lesser loneliness for the individual because a spirit of unity, mutual interdependence, and reciprocal support is encouraged. Nevertheless, as previously suggested, if a particular individual does not conform, then he or she is often severely punished, quite often simply by being excluded from the life of the whole. Exile, ostracism, or even merely ignoring an individual can serve as very efficient forms of punishment. We might recall in this context that Socrates himself refused to choose life if it meant banishment from Athens. So the point is that although there is usually less loneliness-and more of a sense or belonging and sharing-in the organic family, tribe, or community, nevertheless, when there is loneliness, it is often extreme because only one or a few are excluded from the communal life of the whole. A good example of this phenomenon is offered by James Lynch in his discussion of voodoo deaths. When an individual is excluded from the activities of the tribe, the enforced isolation frequently leads to death (Lynch, 1977, p. 59). By contrast, in the atomistic society, since everyone is on his own, the feeling is less lonely because it is more common. In this respect, the individual does not feel different.

Nevertheless, the atomistic society intrinsically generates a preponderance of loneliness among its individuals. As we have already indicated, a number of diverse factors contribute to this sense of loneliness. The political theories of the social contract theorists and the economic free enterprise system of capitalism have already been stressed. But beyond or "beneath" all this there is something else as well and perhaps it is (unfortunately) inherent in the very nature of our democratic social organization and political institutions. It is something which Alexis de 
Tocqueville realized as a necessary element of democratic societies. Describing his impressions upon visiting America in the 1830s, he declared that

In ages of equality all men are independent of each other and isolated and weak (Tocqueville, 1969, p. 439).

One must admit that (democratic) equality, while it brings great benefits to mankind, opens the door, ... to very dangerous instincts. It tends to isolate men from each other so that each thinks only of himself (p. 444).

In aristocratic (and hence organic and hierarchically structured) ages (and social organizations) each man is always bound by close ties to many of his fellow citizens, so that he cannot be attacked without the others coming to his help. In times of equality each man is naturally isolated. He can call on no hereditary friends for help nor on any class whose sympathy for him is assured. He can easily be set upon alone and trodden underfoot. . . Equality isolates and weakens men... Equality deprives each individual of the help of his neighbors (p. 697).

In such a society, the only recourse to injuries or threats lies in the law, and Tocqueville correctly points out that America is unusual in being a country where each person aspires to understand the law. But the law, we must recognize, is an impersonal and abstract system of relations.

Contemporary American society is primarily and overwhelmingly organized along atomistic and contractual principles. Relations between husband and wife, employer and employee, student and teacher, landlord and tenant, bank and homebuyer, doctor and patient, social worker and client are all fundamentally formalistic, legalistic, and rule-oriented. And today, for example, social workers are advised to contract with their clients for services rendered (Garvin and Seabury, 1984). Is it any wonder that we are a lonely society?

When we have difficulties with our spouses we take them to court and file for divorce; we initiate dissolution proceedings. When we have employment disputes, we take the employers to court. Labor unions seek impartial arbitration. When our neighbor has a noisy party, we phone the police. 
Our teachers seldom live in the areas they service; doctors no longer make house calls; computers send out bills; no one marries the boy or girl next door any longer; we leave home to go away to college; no one goes into his father's business any longer; we get jobs in cities we have never seen; we get promotions only if we are willing to relocate; in our ambitions to be upwardly mobile, the stress is on mobility.

Our children are sent to daycare centers so that both parents can work, i.e., be independent; divorce is on the increase; single parent households are increasingly common; we have produced-in the most mechanistic fashion possible-an entire society of fragmented youth, latchkey kids, runaway kids, and throwaway kids. In years long gone by, parents shunned divorce if there were children involved; today, the individual parent's right to happiness comes first.

Emotionally dissatisfied children are increasingly turning to drugs and alcohol and we wonder why. "What is wrong with kids today?" The answer is loneliness. And as the children of divorced parents grow up, get married, and have children of their own, they will repeat the same pattern as their parents (Lynch, 1977, pp. 69-86). We have polluted our social environment and the results will appear to plague us in the future. In our society, all we share is an increasing awareness of separation.

Elsewhere I have argued that loneliness-or more specifically the desire to avoid loneliness-serves as the basic motivational drive in all human beings (Mijuskovic, 1977, 1977a, 1977b, 1977c, 1978, 1979, 1980, 1980a, 1980b, 1981, 1985, in press). Accordingly, the fundamental problem of human existence is grounded in our individual sense of alienation. Assuming that this is the case, then it follows that any social organization which inherently promotes loneliness will be, to that extent, a society wherein a growing number of its individuals are unhappy and suffering from a variety of emotional disorders. The ultimate source of all this discontent will be loneliness.

Can we illustrate just how this happens? I think we can. In many neighborhoods in southern California, Hispanic children attend elementary school with relative ease, even when there is a language difficulty. Their parents encourage them to learn English as well as they can; the children walk to school with 
the same friends year after year; they share lunches and enjoy a strong sense of identity with the Hispanic communities in which they live. In short, their human existence is expressed in and through organic relationships. By the time they have reached high school, something has happened. Few are left and even fewer finish. What has happened? Instead of cooperation, they face competition. If they do not know the answer to the teacher's question, someone else will surely blurt it out. Success is measured entirely in terms of individual grades. There are class standings and individual criteria of popularity. Something has happened indeed. What has occurred is that the Hispanic children have gone from the organic model of community to the atomistic model of the dominant American culture. And no one prepared them for what was about to happen.

What can we in our respective capacities as parents, teachers, social workers, and psychologists do about the atomistic society? What we can do is consciously encourage the values of the organic community and try to balance the picture of human existence so that it is not so skewed in one direction (Cherlin, 1984; Ooms, 1984). To be sure there are dangers in the organic community but there are great benefits as well and we have essentially disregarded the advantages in preparing our children to be "independent." To be independent is to be alone.

Assuming that the foregoing historical, conceptual, and essentially negative analysis of contemporary American society is basically correct, then what are the possible remedies? What sorts of models ought we to use to guide us?

In order to address this more specific issue, let us consider two social units, one fairly large and actual and the second relatively small and ideal. Accordingly, let us first discuss the client population which receives public social services and later the American nuclear family.

A little over two decades ago, public welfare services depended on social workers who divided their time and energies between visiting the homes of the poor and working on budgets. Thus, for example, in Chicago, an ADC (Aid to Dependent Children) caseworker would generally spend two days a week making home visits and seeing families and three days administering fund allocations, handling crises, and filling out forms. 
There was a genuine attempt to individualize grants. For instance, rent allowances varied according to the actual rent paid. Services were more supportive, less investigative in nature. It was not unusual, for example, for caseworkers to become involved in landlord-tenant issues and evictions.

By contrast, today, the grant is administered impersonally by an eligibility technician and it is much more standardized. In addition, the great majority of public social workers, who are employed by the department of social services, represent child protective delivery systems. Their role is initially investigative and subsequently regulative as instruments of the court. Through judicial procedures, social workers have the authority to "remove" children from their homes and formulate a contract conditional for their return. "Protection," primarily physical, of the child clearly takes precedence over helping the family as a whole, as an interdependent organic unit. Whether voluntary (e.g., Dependency Diversion) or court ordered (e.g., Family Reunification) services are provided, in either event contracts are formulated. We rely almost exclusively on a legal, formal remedy to a human problem. The client agrees to "follow through" and perform certain behaviors in order to comply with the court's instructions and thus maintain or resume custody of the child. The contract is essentially based on a behavior modification approach and a stimulus-response model of compliance. But as I have indicated in prior publications, child abuse and neglect derives from parents who suffer from loneliness, anxiety, and hostility; they have failed to resolve earlier abandonment and separation anxiety issues. Abusive parents are, usually, dependent personalities as defined by the DSM-III. They desperately need supportive, nurturing (vs. contractual), organic (vs. atomistic), human (vs. mechanical) interventions. They need to bond emotionally with the provider of services rather than being controlled and manipulated by an impersonal system. One does not have to be a Marxist to realize that the child protective system as it presently operates alienates the mother from the child and the family from society as a whole. Beyond that, to expect unnurtured parents to improve by forcing external, artificial devices is unrealistic precisely because these parents have not developmentally reached that stage of autonomy (Erikson, 
1963, p. 251) at which a contract is meaningful to them. Psychologically they are much more inclined to depend on drugs and alcohol than they are on contracts and standardized treatment plans. Social workers often incorrectly assume their clients lack knowledge and that it is their job as professionals to provide them with facts, information, resources on how to get things done and where. But unnurtured parents already know what has to be done; the difficulty is that they do not care enough. Dependent personalities lack motivation, not knowledge. They are passively dependent and hence abstract contractual systems, which presuppose client autonomy, fail to work because this population needs human services and human attachments. If we can cure their loneliness, we will at the same time endow them with motivation. As Aristotle remarked, the intellect alone moves nothing; only the intellect animated by desire can truly act (McKeon, 1941, VI, 2).

More than twenty years ago, the War on Poverty initiated an organic, comprehensive (as opposed to fragmented) approach to the problems of the poor. It strove to coordinate a balanced effort in terms of housing, employment, education, health, and welfare concerns. The program wisely recognized that solving the housing problem alone, through federally subsidized projects, could not succeed unless comparable achievements were dialectically attained in the other spheres as well. The War on Poverty promoted genuine self-esteem because it encouraged the poor to operate their own programs in their own neighborhoods (the Urban Progress Centers). The tendency of the War on Poverty was in principle organic; it visualized diverse spheres of activity as members of a complete whole and it resisted fragmentation. It promoted a sense of togetherness, belonging. And most importantly it avoided the illusion of quick fixes.

Probably the most successful program funded by the Office of Economic Opportunity was the Headstart program. It was designed to teach disadvantaged children the value and pleasures of learning through sharing and cooperation. It gave them an early sense of positive belonging at a critical stage in their development.

The children came to school; they were fed; any medical problems were immediately addressed; and adequate clothing 
was assured. Nurturance was provided by neighborhood teachers and aides. The kids knew each other and lived within easy walking distance of each other's homes. They were taught to believe that their class was a community.

When years later researchers evaluated the program, they discovered that it was not so much that Headstart children were doing academically better than their peers in school, since the other children caught up to their headstart, but rather that the dropout rate of the Headstart children was comparatively low. They had truly experienced a feeling of belonging in school in those early years that the sadness of their environment could not dull throughout the remaining period of their childhood and adolescence.

Unfortunately, the exigencies of another war froze and destroyed much of the War on Poverty's development and it produced little fruit.

The disastrous tendency to substitute scientific procedures for human attachments and quick fixes for painstaking care also appeared in the field of mental health. Over a quarter of a century ago, in 1962, our society moved toward a deinstitutionalization of mental patients. Medication and short-term, again contractual, therapy would biologically and behaviorally solve the problems of the mentally ill. After all, the brain was basically a biological machine. Find the chemical imbalances, add a little here, subtract a little there, and you have a healthy person. Psychoanalysis took forever; it was too mental, subjective, internal. A competent nurse under the supervision of a psychiatrist could do much more and more quickly than an entire staff of Freudians. After all, human beings are merely sophisticated machines and the mind so-called is simply dependent upon, reducible to, or identical with the brain and the central nervous system. Chemical, atomistic solutions can be found for alleged mental problems.

And now where are we? Countless thousands of homeless individuals, and even families, wander aimlessly on the periphery of our society. These are the absolutely lonely ones, estranged from others and alienated from each other, they are no longer even part of an impersonal system. Their numbers are ever increasing as our atomistic methods have progressively 
failed. They have fallen through the net of care and concern into the abyss of an abandoned existence. If they threaten us, the criminal system will deal with them. But if they are only a danger to themselves, we can safely ignore them. They stand self-condemned for refusing to take their medicine.

As a society, we feel a responsibility to children. Once they have reached eighteen, however, if they have not been integrated into the machinery of our economic world, then they will become the homeless, those whose issues are no longer addressed, if for no other reason than that it is economically prohibitive. These separate, unrelated atoms are no longer part of our system.

I wish to close now with a brief discussion of the American family, by comparing the negative values of today with the more hopeful ones of an earlier time.

Our society is essentially technological and scientific in orientation. And, consequently, we naively rely on a criterion of well being or happiness which is materialistic, individualistic, and based on consumption (Weber, 1958, and Veblen, 1912). But as David Hume showed as early as 1740 , in A Treatise of Human Nature (1955, III, i, p. 1), one cannot derive an ought from an is, a value from a fact; science and ethics are two distinct, i.e., separate, spheres; and one cannot move from one to the other. The American value system assumes, however, that those who are prospering financially are in some significant sense favored and chosen in a moral sense. Hence to do well economically is not only a sign of happiness but indeed of moral well being. Individual freedom and property rights are held as sacred and are often expressed at the expense of social duties. Competition is encouraged and rewarded. These values are in marked contrast to those of a few decades ago. For example, a boy growing up in the 1940s and 1950s would play ball with his friends on his block. It would be the same kids year after year. Although score was kept there were no standings or rivalries against other teams. If there were ten kids, all played; if there were twenty children, all participated. Today, by contrast, a boy registers for Little League (and a girl for Bobby Sox). He goes to a tryout. $\mathrm{He}$ is assigned at least one manager and a coach. There are organized practices, uniforms, umpires, league standings-and a 
bench. If a child does not do well, he will spend a lot of time on the bench. After the season, there are trophies, All Star selections and tournaments. And there are always the supportive parents who evaluate the other team members and the coaches. The criterion is always the same; there are few winners and many losers.

The next year, the kids are on entirely different teams and they are playing against each other rather than with each other.

In the 1950 s college students were intellectually competitive but they incorporated strong productive goals toward society as a whole. During the Viet Nam era, however, college students considered themselves as an influential moral force and they imagined changing the ethical and political direction of the nation by protesting certain policies. They were not particularly interested in an education and often regarded their academic work as an interruption of their primary purpose, which was reformative. Classes had to be relevant, at first morally and, later, after the war, economically. Majors in Liberal Arts declined and business and law schools flourished.Social production (the 1950s) and ethical concerns (the late '60s and early '70s) developed into individual materialistic consumption. The criterion is now simple: Who earns the most, who owns the most? Belonging and sharing-the opposites of loneliness-with our family and friends is no longer a significant value.

Something has gone wrong with our ethical principles, our moral values. And in order to correct it, we must reinvest the family with the Hegelian ideal of "unity through identity in difference." Thus, although members in a family may have different functions, nevertheless they can all share both their feelings and their values together without losing their respective uniqueness. The guiding principle, the ethical ideal of the American family would then lie in a sense of identity through belonging.

In the end, it is a question of values and what we as parents, teachers, and social workers care about. Competition or cooperation? Individual achievement or social sharing? Autonomy or belonging? Both the family and the social model for sharing and belonging have been provided for us historically and as an ideal although we have abandoned them. I am simply suggesting we return more self-consciously to those organic paradigms. 
As Hegel insisted, for either a family or a culture, true freedom is grounded in a rational knowledge of the virtues of a differentiated whole, a unity through multiplicity. It is based on the knowledge that both the family and the culture develop (dialectically) from (a) abstract unity, where the father rules autocratically, to (b) fragmented particularity, in which each person merely follows his own morality, and (c) through final culmination in the ethical and social principle of the good of the whole. The alternatives then are sharing and belong with others versus atomicity and anarchy. The ethical salvation of the family and of the poor (as well as the elderly) is grounded in a rational, i.e., relational, commitment of human beings to each other. All else is alienation.

\section{References}

Bell, G. (1965). Alcohol and loneliness, Journal of Social Therapy, 2, 171-181. Berdyaev, N. (1976). Solitude and society. Westport, CT: Greenwood Press. Cherlin, A. (1984). Family policy. Journal of Family Issues, 5, 155-148.

Durkheim, E. (1958) [197]. Suicide. Glencoe, IL: Free Press.

Erikson, E: (1963) [1950]. Childhood and society. NY: W. W. Norton.

Fromm, E. (1965). Escape from freedom. NY: Avon Books.

Garvin, C. \& Seabury, B. (1984). Interpersonal practice in social work. Englewood Cliffs, NJ: Prentice-Hall.

Hegel, G. The phenomenology of spirit. (1977) [1807]. trans. Miller, A., Oxford, England: Clarendon Press.

Hegel, G. The philosophy of history. (1956) [1837]. trans. Sibree, J., NY: Dover. Hume, D. (1955) [1740]. A treatise on human nature. Oxford, England: Clarendon Press.

Hobbes, T. (1981) [1651]. Leviathan. NY: Penguin.

Kierkegaard, S. (1974) [1843]. Fear and trembling and The sickness unto death. trans. Lowrie, W. Princeton, NJ: Princeton University Press.

Locke, J. (1946) [1690]. The second treatise on civil government. Edited by J. Gough. Oxford, England: Oxford University Press.

Lynch, J. (1977). The broken heart. NY: Basic Books.

McKeon, R. (ed.). The basic works of Aristotle. NY: Random House.

Mijuskovic, B. (1977). Loneliness: An interdisciplinary approach. Psychiatry, 40, 113-132. Reprinted in J. Hartog (Ed.). (1980). The anatomy of loneliness, (pp. 65-94). NY: International Universities Press.

Mijuskovic, B. (1977a). Loneliness and the reflexivity of consciousness. Psychocultural Review, 1, 202-215.

Mijuskovic, B. (1977b). Loneliness and a theory of consciousness. Review of Existential Psychiatry and Psychology, XV, 19-31. 
Mijuskovic. B. (1977c). Types of loneliness. Psychology, 14, 24-29.

Mijuskovic, R. (1978). Loneliness and the possibility of a "private language." The Journal of Thought, 13, 14-21.

Mijuskovic, B. (1978a). Loneliness and time-consciousness. Philosophy today, $22,276-286$.

Mijuskovic, B. (1979). Loneliness and personal identity. Psychology, 16, 11-20. Mijuskovic, B. (1980). Loneliness and narcissism. Psychoanalytic Review, 66, $479-492$.

Mijuskovic, B. (1980a). Loneliness and suicide. The Journal of Social Philosophy, 11, 11-17.

Mijuskovic, B. (1980b). Loneliness and communication. In J. Gracia (Ed.), Man and his conduct, pp. 261-269). Rio Piedras: University of Puerto Rico Press.

Mijuskovic, B. (1981). Loneliness and human nature. Psychological Perspectives, 12, 69-77.

Mijuskovic, B. (1985). Loneliness. Second Edition. NY: Associated Faculty Press.

Mijuskovic, B. Counseling and loneliness. Adolescence, in press.

Mill, J. (1981) [1859]. On Liberty. NY: Appleton-Century-Crofts.

Ooms, T. (1984). The necessity of a family perspective. Journal of Family Issues, $5,170-171$.

Orwell, G. (1949). 1984. NY: Harcourt, Brace.

Plato, (1957). The republic. Trans. F.M. Cornford. Oxford, England: Oxford University Press.

Riesman, D., Glazer, N. and Denny, R. (1958). The lonely crowd. New Haven: Yale University Press.

Rousseau, J-J. (1973) [1762]. The social contract, and Discourses. Trans. E.H.D. Cole. NY: Dutton.

Tocqueville, A. de. (1969) [1835]. Democracy in America. NY: Doubleday.

Tonnies, F. (1957) [1887]. Community and society. Trans. C. Loomis. East Lansing, MI: Michigan State University Press.

Veblen, T. (1912) [1899], The theory of the leisure class. NY: Macmillan.

Weber, M. (1958) [1906]. The protestant ethic and the spirit of capitalism. NY: Scribners. 


\section{CONTRIBUTORS}

Janice Andrews

University of St. Thomas/

College of St. Catherine

Department of Social Work

2115 Summit Avenue

St. Paul, Minnesota 55105

Darlyne Bailey

Case Western Reserve University

Mandel School of Applied Social Sciences

Cleveland, Ohio 44106

Stig Berg

University of Goteborg

Department of Geriatric and Long-Term Care Medicine

Institute of Gerontology

Jonkoping, Sweden

Margareta Carlsson-Agren

University of Goteborg

Department of Geriatric and

Long-Term Care Medicine

Institute of Gerontology

Jonkoping, Sweden

Address for correspondence:

Margareta Carlsson-Agren

6451 SW 116 Ct., Unit D

Miami, FL 33173

E. Wayne Carp

Pacific Lutheran University

Department of History

Tacoma, WA 98447

Pranab Chatterjee

Case Western Reserve University Mandel School of Applied Social

Sciences

Cleveland, Ohio 44106
Thomas Maher

University of Louisville

Kent School of Social Work

Oppenheimer Hall

Louisville, KY 40292

Ben Mijuskovic

County of San Diego

Department of Health Services

Mental Health Services

San Diego, California

Thomas Packard

San Diego State University

School of Social Work

San Diego, CA 92182

Karen Tice

University of Kentucky

College of Education

Educational Policy Studies and

Evaluation

131 Taylor Education Building

Lexington, KY 40506-0001

Linda Cherrey Reeser

Western Michigan University

School of Social Work

Kalamazoo, MI 49008-5034

Claes-Goran Wenestam

Abo Academy

Department of Teacher Education

Vasa, Finland 
